GSA Data Repository Item 2016164

Sinclair, H.D., Mudd, S.M., Dingle, E., Hobley, D.E.J., Robinson, R., and Walcott, R., 2016, Squeezing river catchments through tectonics: Shortening and erosion across the Indus Valley, NW Himalaya: GSA Bulletin, doi:10.1130/B31435.1.

\title{
OSL Analyses
}

\section{SAMPLE PREPARATION}

Samples were prepared using standard OSL procedures. Material was desiccated at $50{ }^{\circ} \mathrm{C}$ to enable calculation of water content, and then sieved to extract the 180-212 $\mu \mathrm{m}$ grain size fraction. Approximately $10 \mathrm{~g}$ of the $180-212 \mu \mathrm{m}$ grain size fraction was treated with $30 \% \mathrm{HCl}$ for $30 \mathrm{~min}$ to remove $\mathrm{CaCO}_{3}$. Samples were agitated throughout the treatment, and once complete, $\mathrm{HCl}$ was replaced with $30 \% \mathrm{H}_{2} \mathrm{O}_{2}$ to remove organic material. The duration of $\mathrm{H}_{2} \mathrm{O}_{2}$ treatment varied between samples, dependent upon the amount of organic material present, and two $\mathrm{H}_{2} \mathrm{O}_{2}$ treatments were necessary for some samples with a high organic content. Once effervescence ceased, the $\mathrm{H}_{2} \mathrm{O}_{2}$ was decanted, the sample was washed four times with deionised water and desiccated at $50{ }^{\circ} \mathrm{C}$. Quartz is extracted from polymineral sediment residues through density separations using LST fastfloat (sodium heteropolytungstate dissolved in deionized water). Heavy minerals $\left(>2.68 \mathrm{~g} \mathrm{~cm}^{-3}\right)$ were separated from the lighter fraction, and the target $2.58-2.68 \mathrm{gcm}^{-3}$ fraction was further separated from the $<2.58 \mathrm{~g} \mathrm{~cm}^{-3}$ material. The target fraction was washed five times with deionised water to ensure removal of all LST. Final separates were dried and etched with $40 \% \mathrm{HF}$ for $40 \mathrm{~min}$ to remove any contaminating feldspar; all samples were agitated at $5 \mathrm{~min}$ intervals throughout treatment. The etched quartz was treated with $30 \% \mathrm{HCl}$ for $30 \mathrm{~min}$ to remove any carbonates produced during HF etching.

\section{LUMINESCENCE MEASUREMENTS}

All analyses were carried out using either a TL-DA-15 or TL-DA-20 Risø reader, equipped with an EMI 9235QA photomultiplier and $7.5 \mathrm{~mm}$ Hoya U-340 filter. Blue (470 \pm $20 \mathrm{~nm})$ and infrared $(\sim 870 \mathrm{~nm})$ diodes operated at $90 \%$ and $40 \%$ power, respectively, were used for stimulation and irradiation was achieved using a ${ }^{90} \mathrm{Sr} /{ }^{90} \mathrm{Y}$ beta source. Readers were calibrated using quartz prepared at the Risø National Laboratory in Denmark. Quartz was applied to stainless steel discs $(10 \mathrm{~mm} \varnothing, 1 \mathrm{~mm}$ thick) using silicon grease and the aliquot size was regulated using a small $(2 \mathrm{~mm} \emptyset, \sim 35$ grain) mask.

Samples were analyzed using the single aliquot regenerative dose (SAR) protocol (Murray and Wintle, 2000). The equivalent dose $\left(D_{e}\right)$ was calculated from measurements of the luminescence response following stimulation of the natural luminescence $\left(L_{n}\right)$ and a series of different regenerative doses $\left(L_{x}\right)$ (Table DR1). The $L_{n}$ and $L_{x}$ measurements are normalized by measurement of the luminescence response $\left(T_{x}\right)$ to a constant test dose $\left(T_{D}\right)$. The ratio $L_{X} / T_{X}$ is used to compensate for sensitivity changes of the quartz throughout analysis and $L_{X} / T_{X}$ measurements are used to obtain a range of values which bracket $L_{n} / T_{X}$, allowing $D_{e}$ interpolation with minimal associated errors (Banerjee et al., 2000).

The sample is heated prior to making the luminescence measurements in order to reduce the contribution of luminescence from unstable trap, which cause erroneous dose determinations. The temperature of the pre- $L_{x}$ pre-heat (PH1) and the pre- $T_{x}$ pre-heat (PH2) must be empirically determined for each sample under analysis. This was achieved through analysis of 8 disks with a dose-recovery pre-heat plateau experiment (Murray and Wintle, 2003), using a range of $\mathrm{PH} 1$ and $\mathrm{PH} 2$ temperatures ranging from $150-220{ }^{\circ} \mathrm{C}$. The influence of a hot-bleach at $280^{\circ} \mathrm{C}$ was also investigated (Murray and Wintle, 2003) and used on any samples experiencing thermal transfer and recuperation. 
GSA Data Repository Item 2016164

Sinclair, H.D., Mudd, S.M., Dingle, E., Hobley, D.E.J., Robinson, R., and Walcott, R., 2016, Squeezing river catchments through tectonics: Shortening and erosion across the Indus Valley, NW Himalaya: GSA Bulletin, doi:10.1130/B31435.1.

The SAR protocol with a $\mathrm{PH} 1$ of $180-220^{\circ} \mathrm{C}$ used on the samples is provided in Table DR1. Aliquot acceptance criteria used are (1) recycling ratios within $10 \%$ of unity; (2) signal intensities ${ }^{3} 3 \sigma$ above background; (3) infrared (IR) depletion ratio within $20 \%$ of unity (Duller, 2003); (4) $D_{e}$ uncertainty $\leq 20 \%$ and (5) recuperation within $10 \%$ of the normalized maximum dose. The acceptance thresholds are moderate - high for the samples reflecting a range of sensitivities for quartz in the samples. The total aliquots accepted for the samples therefore varies; $>50$ ( 6 samples), $>40$ ( 7 samples), >30 (13 samples) and between 15 and 30 aliquots (4 samples).

\section{ENVIRONMENTAL DOSE RATE DETERMINATION}

The environmental dose rates $\left(D_{r}\right)$ were calculated for each sample from the unsieved portions of the original sample; concentrations of $\mathrm{U}, \mathrm{Th}, \mathrm{K}$ and $\mathrm{Rb}$ were measured directly using solution ICP-MS (Thermo X-Series), a cosmic-dose component after Prescott and Hutton (1994) and an internal alpha dose rate of 5\% from the decay of $U$ and Th after Sutton and Zimmerman (1978). External $\alpha$-dose rates were ignored as the alpha irradiated portion of quartz grains was removed by etching. The conversion factors of Adamiec and Aitken (1998) and beta-particle attenuation factors after Mejdahl (1979) have been used. Sample water content was calculated following desiccation at $50{ }^{\circ} \mathrm{C}$, and an uncertainty of $5 \%$ assumed. Table DR2 contains the dosimetry data for the OSL samples from the southwestern and northeastern margins of the Shyok Valley.

\section{ANALYSIS OF RESULTS}

Most samples are characterized by large overdispersion values (broad $D_{e}$ distributions) which describe the spread in the data not accounted for by analytical uncertainties (Galbraith and Roberts, 2012). Samples with overdispersion, greater than $20 \%$, are assumed to reflect heterogeneous bleaching before deposition and the $D_{e}$ data were analyzed within Excel to calcualate overdispersion and statistical parameters that are used to model the appropriate burial age $\left(D_{b}\right)$. We adopted the age model selection criteria of Arnold and Roberts (2009). Most samples are modeled using the three component minimum age model (MAM-3; Galbraith et al., 1999) and the RStudio Luminescence package (Kreutzer et al., 2013), and two samples are modeled with a central age model. The kernel density and radial plots are presented in Figure DR2A and DR2B for each sample and the dosmietry and $D_{e}$ data are presented in Table DR2.

\section{REFERENCES CITED}

Adamiec, G., and Aitken, M.J., 1998, Dose-rate conversion factors: update: Ancient TL, v. 16, p. $37-46$.

Arnold, L.J., and Roberts, R.G., 2009, Stochastic modelling of multi-grain equivalent dose (De) distributions: implications for OSL dating of sediment mixtures: Quaternary Geochronology, v. 4, p. 204-230, doi:10.1016/j.quageo.2008.12.001.

Banerjee, D., Botter-Jensen, L., and Murray, A.S., 2000, Retrospective dosimetry: estimation of the dose to quartz using the single-aliquot regenerative-dose protocol: Applied Radiation and Isotopes, v. 52, p. 831-844, doi:10.1016/S0969-8043(99)00247-X. 
GSA Data Repository Item 2016164

Sinclair, H.D., Mudd, S.M., Dingle, E., Hobley, D.E.J., Robinson, R., and Walcott, R., 2016, Squeezing river catchments through tectonics: Shortening and erosion across the Indus Valley, NW Himalaya: GSA Bulletin, doi:10.1130/B31435.1.

Duller, G.A.T., Bøtter-Jensen, L., and Murray, A.S., 2003, Combining infrared-and greenlaser stimulation sources in single-grain luminescence measurements of feldspar and quartz: Radiation Measurements, v. 37(4), p. 543-550.

Galbraith, R.F., and Roberts, R.G., 2012, Statistical aspects of equivalent dose and error calculation and display in OSL dating: an overview and some recommendations: Quaternary Geochronology, v. 11, p. 1-27, doi:10.1016/j.quageo.2012.04.020.

Galbraith, R.F., Roberts, R.G., Laslett, G.M., Yoshida, H., and Olley, J.M., 1999, Optical dating of single and multiple grains of quartz from jinmium rock shelter, northern Australia, part 1, Experimental design and statistical models: Archaeometry, v. 41, p. 339-364, doi:10.1111/j.1475-4754.1999.tb00987.x.

Kreutzer, S., Schmidt, C., Fuchs, M.C., Dietze, M., Fischer, M., and Fuchs, M., 2013, Introducing an R package for luminescence dating analysis: Ancient TL, v. 30, p. 1-8.

Mejdahl, V., 1979, Thermoluminescence Dating: Beta-Dose Attenuation in Quartz Grains.

Murray, A.S., and Wintle, A.G., 2000, Luminescence dating of quartz using an improved single aliquot regenerative dose protocol: Radiation Measurements, v. 32, p. 57-73, doi:10.1016/S1350-4487(99)00253-X.

Murray, A.S., and Wintle, A.G., 2003, The single aliquot regenerative dose protocol: potential for improvements in reliability: Radiation Measurements, v. 37, p. 377-381, doi:10.1016/S1350-4487(03)00053-2.

Prescott, J.R., and Hutton, J.T., 1994, Cosmic ray contributions to dose rates for luminescence and ESR dating: Large depths and long-term time variations: Radiation Measurements, v. 23, p. 497-500, doi:10.1016/1350-4487(94)90086-8.

Sutton, S.R., and Zimmerman, D.W., 1978, Thermoluminescence dating: radioactivity in quartz: Archaeometry, v. 20, p. 67-69, doi:10.1111/j.1475-4754.1978.tb00214.x.

\section{FIGURE CAPTIONS}

Figure DR1. Sedimentary log through the T1 terrace fill at Spituk. Left hand column is thickness of beds in centimeters. Second column is bed number.

Figure DR2. Sedimentary log through the T2 terrace fill at Spitka which is on southwestern margin of the Indus Valley opposite Spituk. Grid Ref: $34.11683^{\circ}, 77.51964$.

Figure DR3. Location of Swath that generated the mean topographic values illustrated in Figure 8A.

Figure DR2A. Kernel density and radial plots for each OSL sample from the southwestern margin of Indus valley. These plots both present the $D_{e}$ distributions and uncertainties and illustrate the spread in the data and how the minimum or central age modeled (Table DR1) maps onto the distributions. Sample name is provided at the top of the kernel density plot.

Figure DR2B. Kernel density and radial plots for each OSL sample from the northeastern margin of Shyok Valley. 
GSA Data Repository Item 2016164

Sinclair, H.D., Mudd, S.M., Dingle, E., Hobley, D.E.J., Robinson, R., and Walcott, R., 2016, Squeezing river catchments through tectonics: Shortening and erosion across the Indus Valley, NW Himalaya: GSA Bulletin, doi:10.1130/B31435.1.

TABLE DR1. AN EXAMPLE QUARTZ SAR PROTOCOL USED FOR THE LADAKH SAMPLES

\begin{tabular}{ll}
\hline \hline Natural/Regenerative Dose & $20,50,75,100,0,10,10 \mathrm{~Gy}$ \\
TL (PH1) & $180-200^{\circ} \mathrm{C}, 10 \mathrm{~s}, 5^{\circ} \mathrm{C} / \mathrm{s}$ \\
IRSL (final cycle only) & $20^{\circ} \mathrm{C}, 40 \mathrm{~s}, 5^{\circ} \mathrm{C} / \mathrm{s}$ \\
OSL & $125^{\circ} \mathrm{C}, 40 \mathrm{~s}, 5^{\circ} \mathrm{C} / \mathrm{s}, 90 \%$ power $(L x)$ \\
Test Dose & $20 \mathrm{~Gy}$ \\
TL (PH2) & $180^{\circ} \mathrm{C}, 10 \mathrm{~s}, 5^{\circ} \mathrm{C} / \mathrm{s}$ \\
OSL & $125^{\circ} \mathrm{C}, 40 \mathrm{~s}, 5^{\circ} \mathrm{C} / \mathrm{s}, 90 \%(T x)$ \\
TL (hot bleach) & $280^{\circ} \mathrm{C}, 40 \mathrm{~s}, 5^{\circ} \mathrm{C} / \mathrm{s}, 90 \%$ \\
\hline
\end{tabular}

TABLE DR2. LOCATIONS OF DATED SAMPLES

\begin{tabular}{lcc}
\hline \hline Sample & $\begin{array}{c}\text { Latitude } \\
\left({ }^{\circ} \mathrm{N}\right)\end{array}$ & $\begin{array}{c}\text { Longitude } \\
\left({ }^{\circ} \mathrm{E}\right)\end{array}$ \\
\hline Markha2011-01 & 34.11998 & 77.42213 \\
Markha2011-02 & 34.11998 & 77.42213 \\
Markha2011-05 & 34.11998 & 77.42213 \\
Markha2011-06 & 34.12009 & 77.42102 \\
Spituk2011-01 & 34.1309 & 77.52539 \\
Dung2011-01 & 34.11691 & 77.51977 \\
Dung2011-02 & 34.11691 & 77.51977 \\
Dung2011-03 & 34.115 & 77.52248 \\
Basgo2011-01 & 34.226 & 77.26396 \\
Basgo2011-02 & 34.226 & 77.26396 \\
Basgo2011-03 & 34.22578 & 77.267 \\
Zansk2011-01 & 34.13588 & 77.27848 \\
Zansk2011-02 & 34.13588 & 77.27848 \\
Nimmu2011-01 & 34.20192 & 77.34215 \\
Nimmu2011-02 & 34.20128 & 77.34131 \\
Nimmu2011-03 & 34.18956 & 77.36797 \\
Nimmu2011-04 & 34.18956 & 77.36797 \\
\hline
\end{tabular}


GSA Data Repository Item 2016164

Sinclair, H.D., Mudd, S.M., Dingle, E., Hobley, D.E.J., Robinson, R., and Walcott, R., 2016, Squeezing river catchments through tectonics: Shortening and erosion across the Indus Valley, NW Himalaya: GSA Bulletin, doi:10.1130/B31435.1.

TABLE DR3 DOSIMETRY, EQUIVALENT DOSE (DE) AND OSL AGE ESTIMATES LADAKH SAMPLES

\begin{tabular}{|c|c|c|c|c|c|c|c|c|c|c|c|c|c|c|c|c|c|c|c|}
\hline Sample & $\begin{array}{c}U \\
(\mathrm{ppm}) \\
\end{array}$ & $\begin{array}{l}\text { Error } \\
(\mathrm{ppm})\end{array}$ & $\begin{array}{c}\begin{array}{c}\text { Th } \\
(\mathrm{ppm})\end{array} \\
\end{array}$ & $\begin{array}{l}\text { Error } \\
(\mathrm{ppm})\end{array}$ & $\begin{array}{c}K \\
(\%) \\
\end{array}$ & $\begin{array}{c}\text { Error } \\
(\%)\end{array}$ & $\begin{array}{c}\mathrm{Rb} \\
(\mathrm{ppm})\end{array}$ & $\begin{array}{l}\text { Error } \\
(\mathrm{ppm})\end{array}$ & $\begin{array}{c}\mathrm{H}_{2} \mathrm{O} \\
\text { content }\end{array}$ & $\begin{array}{l}\begin{array}{c}\text { Cosmic } \\
\left(\mathrm{mGya}^{-1}\right)\end{array} \\
\end{array}$ & $\begin{array}{l}\text { Error } \\
(10 \%) \\
\end{array}$ & $\begin{array}{l}\text { Total Qtz } \\
\left(\mathrm{mGya}^{-1}\right)\end{array}$ & $\begin{array}{c}\text { Error } \\
\left(\mathrm{mGya}^{-1}\right)\end{array}$ & $\mathrm{N}$ & $\begin{array}{l}\mathrm{De} \\
\mathrm{Gy}\end{array}$ & $\begin{array}{c}\text { Error } \\
\text { Gy }\end{array}$ & $\begin{array}{c}\text { Age } \\
\text { ka }\end{array}$ & $\begin{array}{c}\text { Error } \\
\mathrm{ka}\end{array}$ & $\begin{array}{c}\text { Age } \\
\text { Model }\end{array}$ \\
\hline Markha2011-1 & 1.479 & 0.044 & 7.87 & 0.236 & 1.499 & 0.045 & 70.88 & 7.088 & 0.5 & 0.036 & 0.004 & 1.541 & 0.047 & 56 & 54.88 & 3.85 & 35.60 & 2.73 & MAM-3 \\
\hline Markha2011-2 & 1.801 & 0.054 & 9.252 & 0.278 & 1.662 & 0.050 & 86.46 & 8.646 & 0.6 & 0.036 & 0.004 & 1.638 & 0.047 & 59 & 119.60 & 6.98 & 73.01 & 4.76 & MAM-3 \\
\hline Markha2011-5 & 1.596 & 0.048 & 7.109 & 0.213 & 1.287 & 0.039 & 70.53 & 7.053 & 0.4 & 0.036 & 0.004 & 1.501 & 0.049 & 36 & 59.98 & 7.55 & 39.97 & 5.19 & MAM-3 \\
\hline 2011-6 & 1.814 & 0.054 & 6.839 & 0.205 & 0.906 & 0.027 & 51.77 & 5.177 & & & 0.0 & & 0.066 & 20 & 114.52 & 16.53 & 77.22 & 11.67 & MAM-3 \\
\hline & 2.009 & 0.060 & 8.749 & 0.262 & 0.937 & 0.028 & 49.35 & 4.9 & & & & & & 31 & 56.65 & 5.85 & 27.52 & 3.03 & \\
\hline & 2.532 & 0.076 & 11.83 & 0.355 & 1.78 & 0.053 & 98.35 & 9.835 & 0.4 & & & & & 53 & & 1.59 & 11.74 & 0.68 & MAM-3 \\
\hline Dung2011-2 & 2.594 & 0.078 & 12.48 & 0.374 & 1.92 & 0.058 & 109.9 & 10.99 & & & & & 0.084 & 53 & 51.29 & 1.10 & 19.11 & 0.73 & CAM \\
\hline & 3.466 & 0.104 & 13.16 & 0.395 & 1.875 & 0.056 & 107.8 & 10.78 & & & & & & 53 & & & 21.98 & 1.33 & \\
\hline & 1.64 & .049 & 10.68 & 0.320 & 2.489 & 0.075 & 101 & 10. & & & & & & 39 & & & 19.08 & 3.45 & \\
\hline $011-2$ & 1.414 & 0.042 & 7.592 & 0.228 & 2.011 & 0.060 & 66 & & 0.4 & 0.056 & 0.006 & 1.99 & 0.067 & 37 & 17.49 & 1.60 & 8.78 & 0.86 & MAM-3 \\
\hline $11-3$ & 0.778 & 0.023 & 4.5 & 0.135 & 2.086 & 0.063 & 66.88 & 6.68 & & & & & & 25 & & & & 1.29 & CAM \\
\hline & 2.051 & 0.062 & 9.959 & 0.29 & 0.81 & 0.02 & & & & & & & & 15 & & & 19. & 6.67 & MAM-3 \\
\hline & 1.173 & 0.035 & 5.356 & 0.161 & 1.144 & 0.034 & 45.17 & 4.5 & 0. & & & & & 35 & 59.50 & 18.80 & 39.32 & 12.49 & MAM-3 \\
\hline Nimn & 1.504 & 0.045 & 5.518 & 0.166 & 1.159 & 0.035 & 50.25 & 5.02 & 0. & & & & 0.050 & 16 & 41.65 & 5.67 & 28.76 & 4.04 & MAM-3 \\
\hline & 1.586 & & 9.4 & 0.2 & 1.26 & 0.03 & & & & & & & & 34 & & & 18. & 1.88 & \\
\hline Nimm & 1.831 & 0.055 & 7.82 & 0.235 & 0.813 & 0.024 & 52.3 & 5.23 & 0.1 & 0.282 & 0.028 & 1.870 & 0.071 & 45 & 23.88 & 1.53 & 12.77 & 0.95 & MAM-3 \\
\hline Nimmu2011-4 & 2.142 & 0.064 & 8.464 & 0.254 & 0.982 & 0.029 & 53.79 & 5.379 & 0.1 & 0.282 & 0.028 & 2.123 & 0.081 & 55 & 24.28 & 1.70 & 11.44 & 0.91 & MAM-3 \\
\hline
\end{tabular}


Supplementary figure 1 , Sinclair et al.

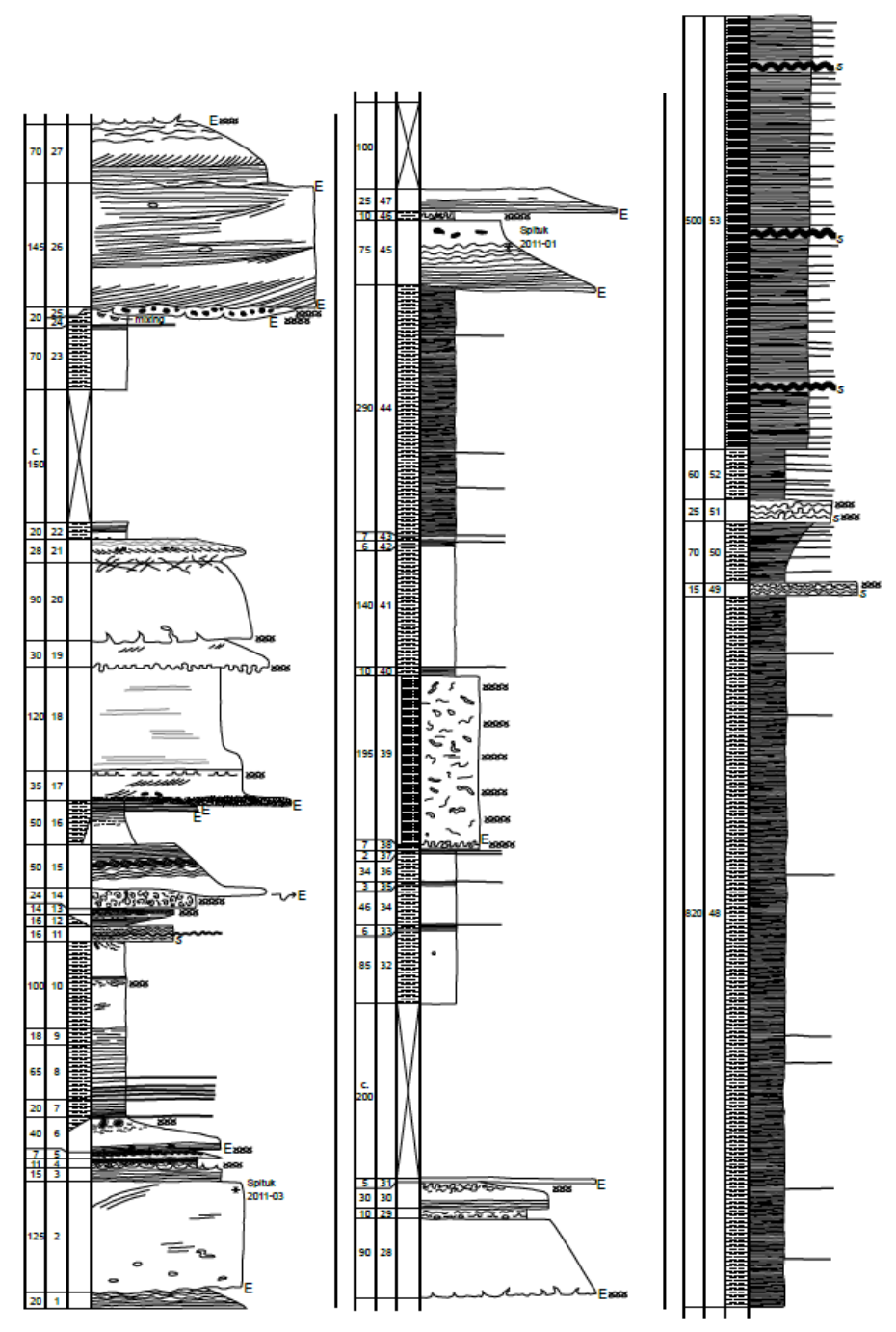


Supplementary figure 2 , Sinclair et al.

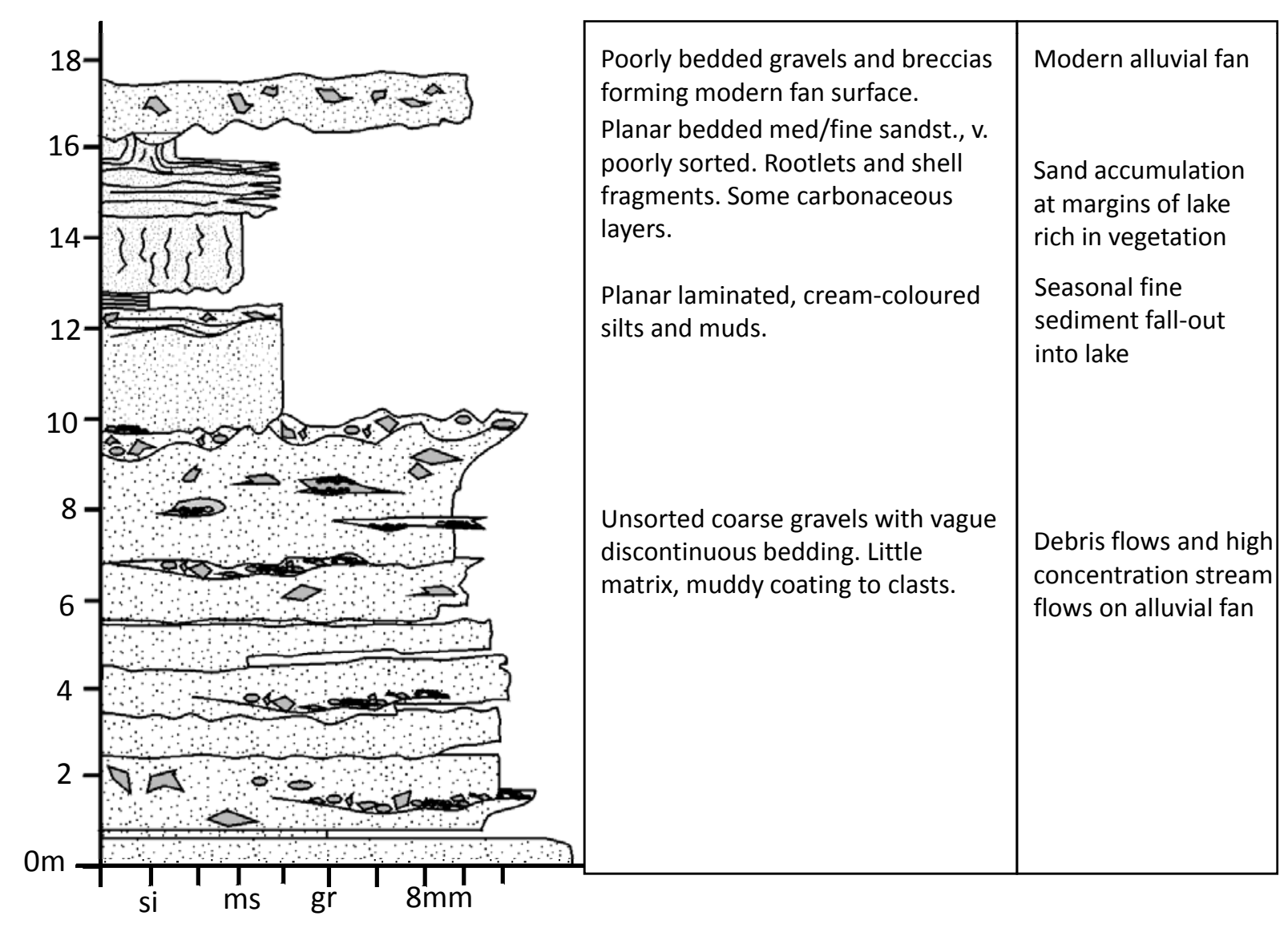


Supplementary figure 3 , Sinclair et al.

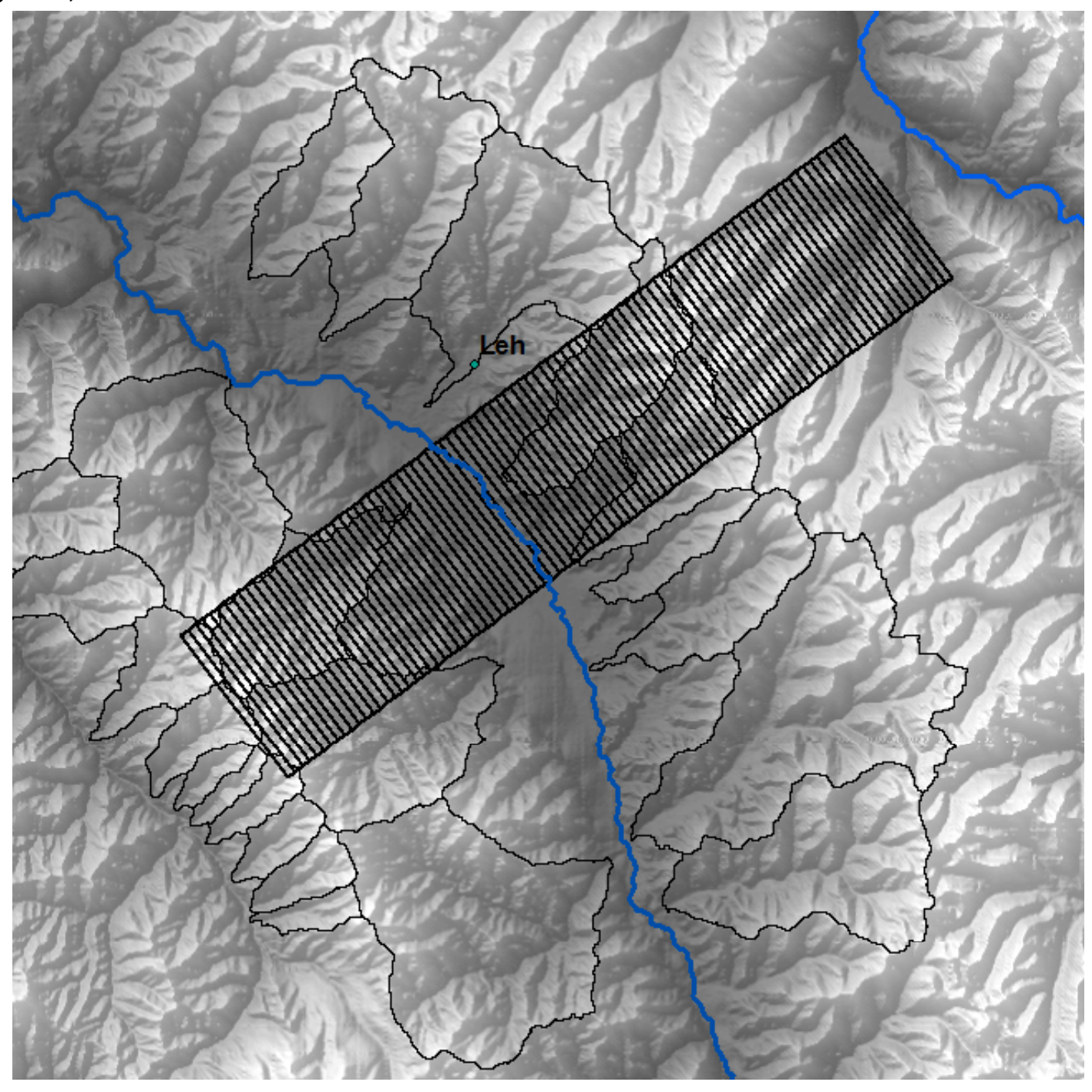


A.

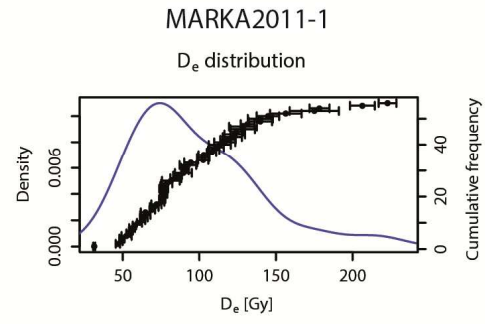

B.

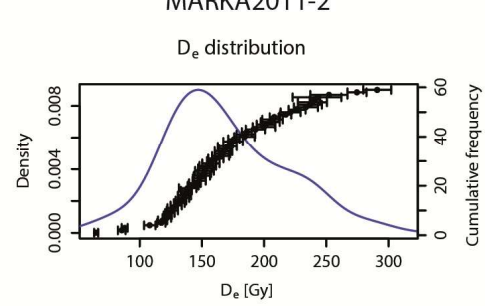

C.

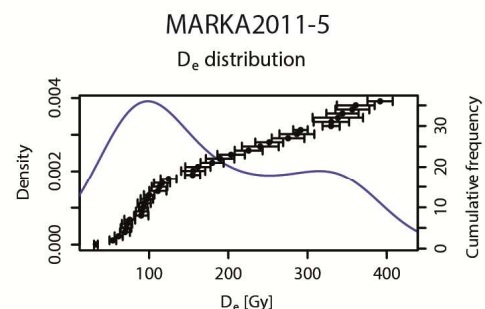

D.

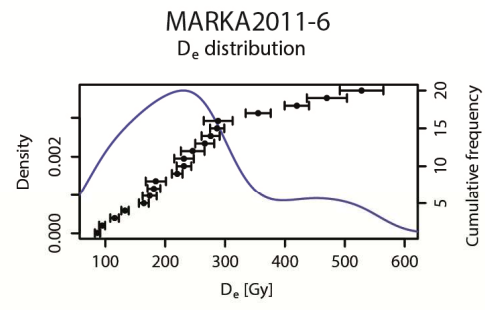

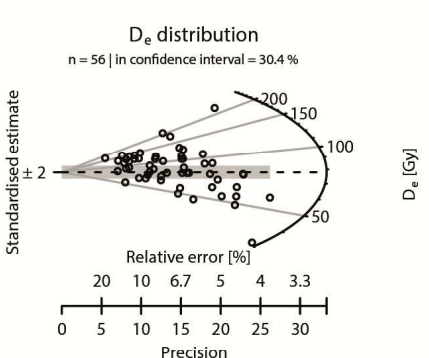
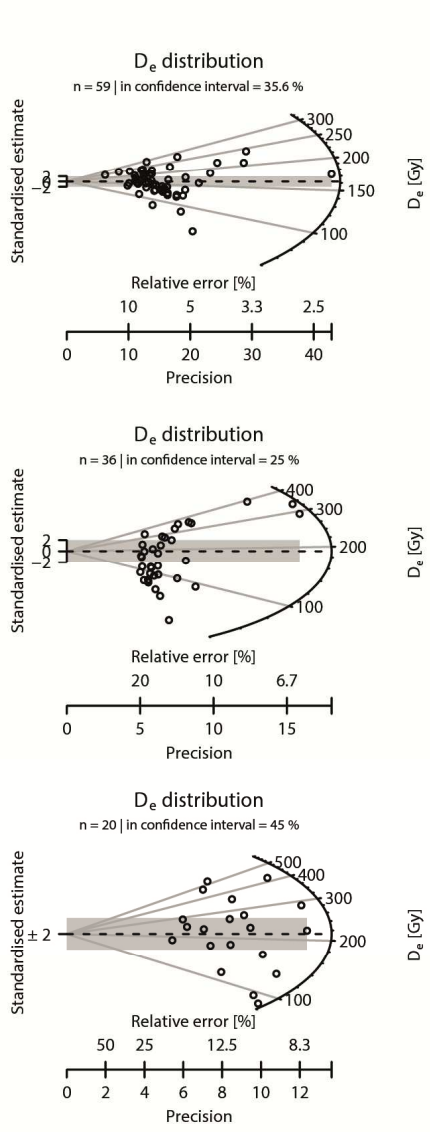

E.

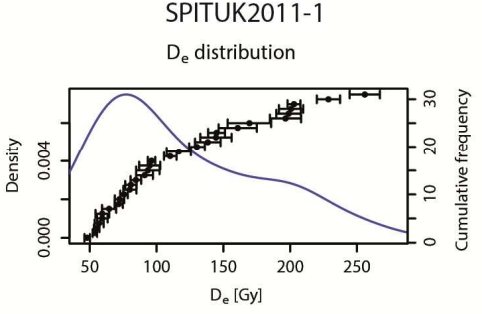

F.

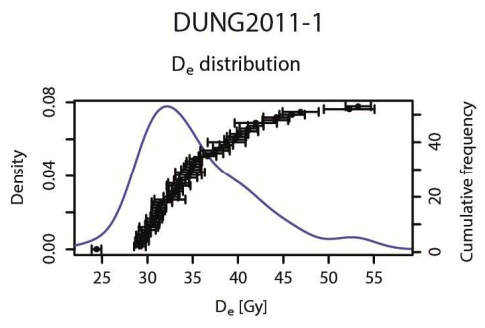

G.

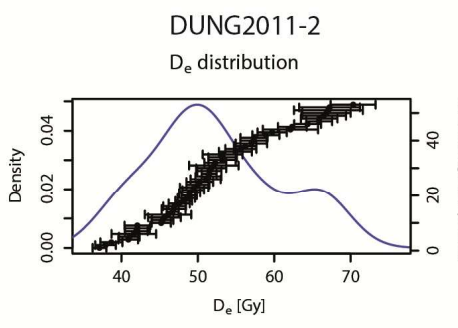

H.

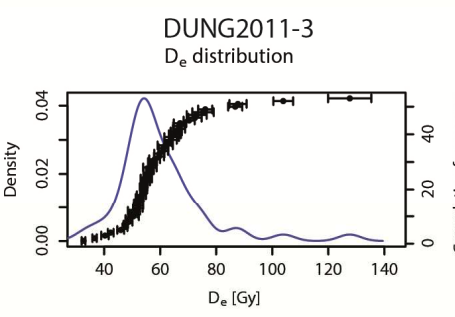

$D_{e}$ distribution

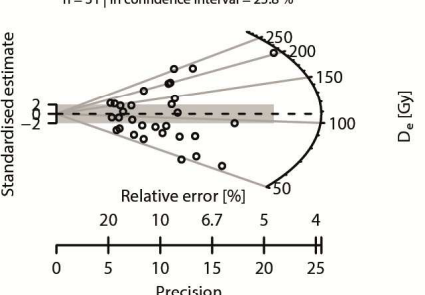

$D_{e}$ distribution
$=533$ in confidence interval $=520$.

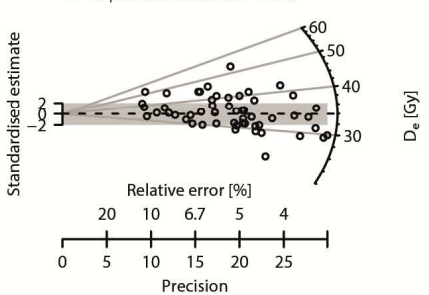

$D_{e}$ distribution

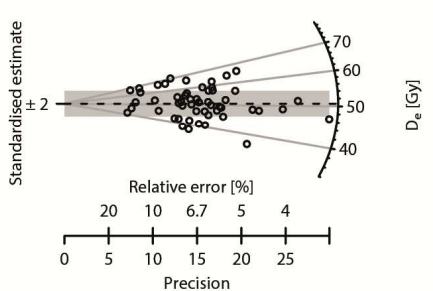

$D_{e}$ distribution

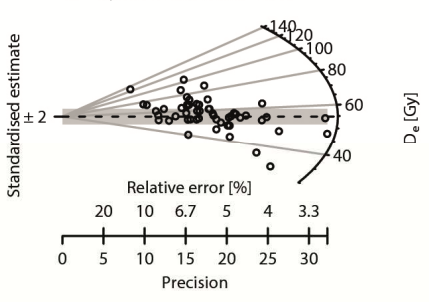


8

A.

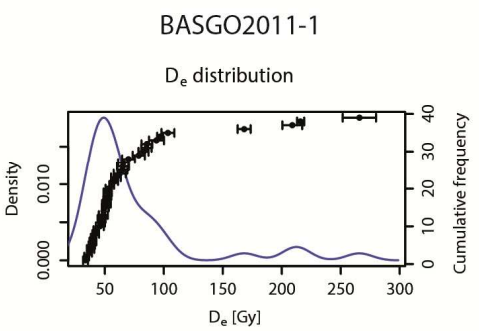

B.

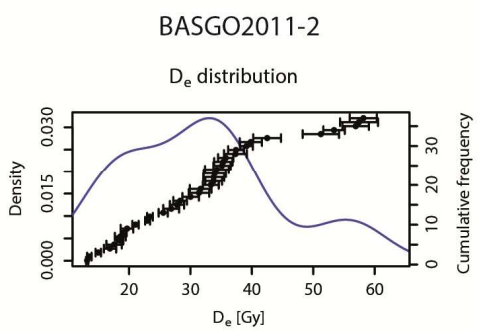

c.

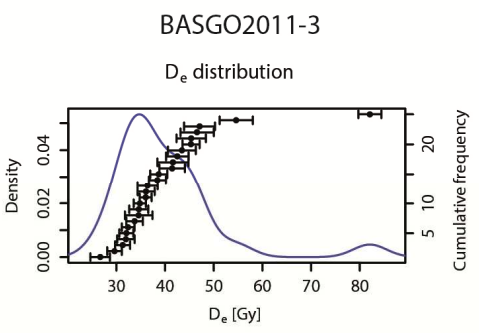

D.

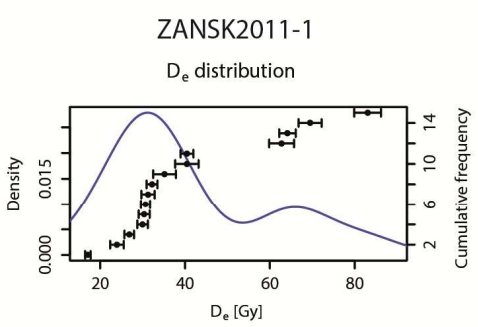

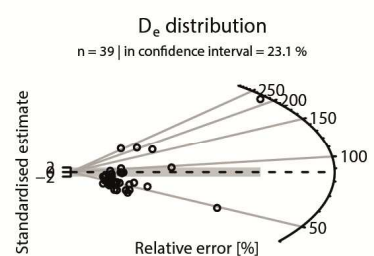
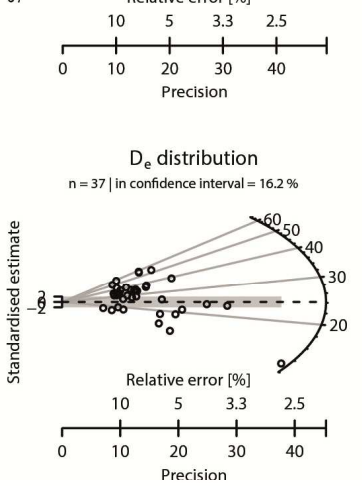

$D_{e}$ distribution

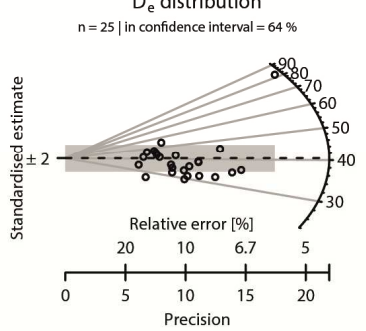

$D_{e}$ distribution

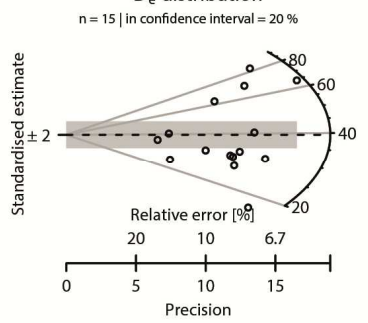

E.

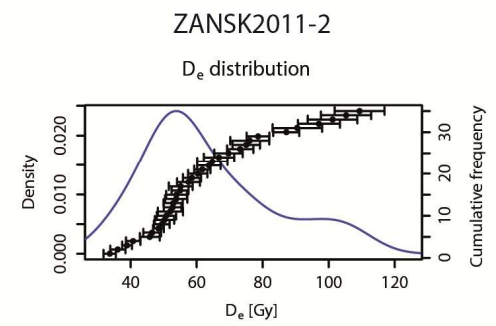

F.

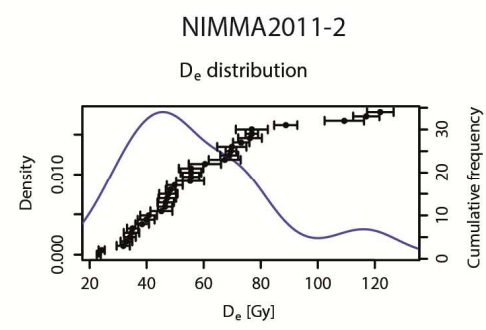

G.

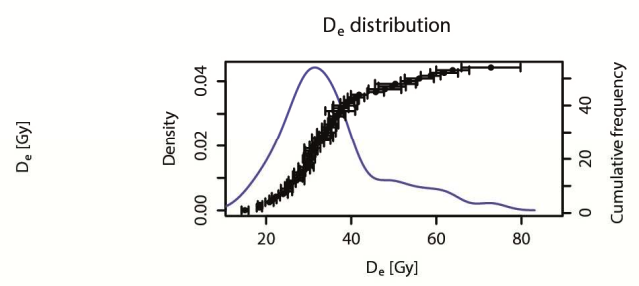

$\mathrm{H}$.

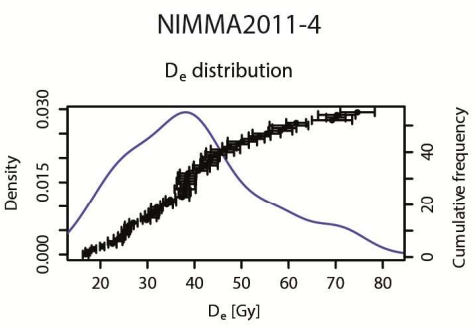

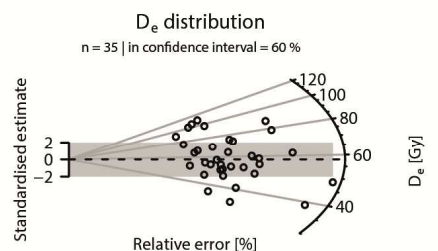

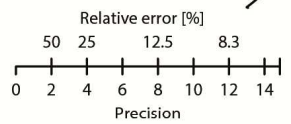

$D_{e}$ distribution

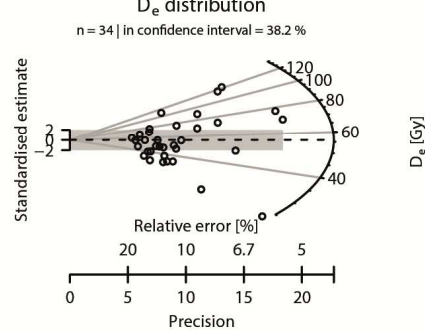

$D_{e}$ distribution

$\mathrm{n}=54 \mid$ in confidence interval $=48.1 \%$

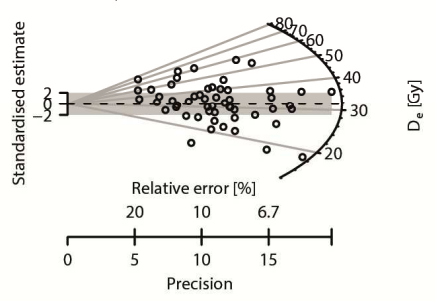

$D_{e}$ distribution

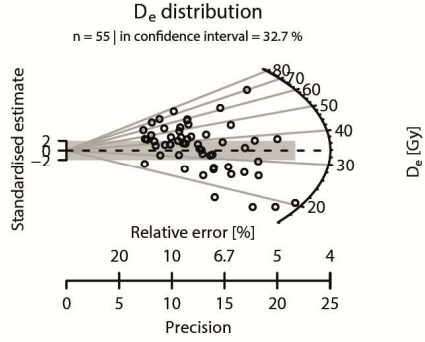

